\title{
A linguistic analysis of sexist statements by Janusz Korwin-Mikke
}

\author{
Kamila Kuros \\ e-mail: kamila1702@o2.p1
}

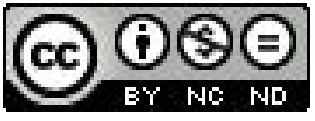

\begin{abstract}
In the following paper the author has performed a linguistic analysis of several chosen sexist remarks by Janusz Korwin-Mikke in order to prove how stereotypically women are regarded by the famous politician. This conservative man treats stereotypes as a proof of good order and fights to prevent women from trying to change what for thousands of years has given the general order and happiness for male sex and, in his opinion, for female sex. Significant for the author's paper has been the importance of antifeminist's texts within pragmatic and semantic aspect. The paper has concentrated on solely the linguistic aspect - in detail there have been discussed among other things: aphorisms and neologisms which are used by the controversial politician. In the paper the author has tried to prove that J. KorwinMikke's language provokes and insults the opposite sex.
\end{abstract}

Keywords: the Polish language, sex, antifeminism, a linguistic picture of the world

Janusz Korwin-Mikke, as a politician and polish publicist, is famous for his radical and extremely bold views. One cannot deny that he is broadly educated and well-known for his erudition. However, a lot of people are irritated by his line of thought. He is commonly considered to be a conservative and an eccentric. He formulates his opinions very consciously and in a daring manner. His peculiar way of thinking is depicted by numerous intriguing metaphors. He is mainly interested in politics and gender issues. According to him, women are not equal to men. His words of wisdom induce public reflection. Women, especially feminists, do not hide their antipathy to this well-known politician. Any signs of discontent on the part of frustrated women only intensify his cutting remarks. In order to express what appalls him, J. Korwin-Mikke does not avoid arguable neologisms. He also uses vulgarisms in various contexts, but - as a gentleman - tries to cover them, but only in a graphical sense. However, what he really wants to express is obvious. 
It is worth carrying out a linguistic analysis of selected fragments of J. Korwin Mikke's statements and necessary to understand the peculiar way of portraying women by this controversial male representative.

To start with, it would be reasonable to focus on statements containing the lexemes "woman" and "man" in order to analyse how those two words evaluate each gender.

J. Korwin-Mikke's statements contain crude nouns describing women, for example "slut", "old bag", "Barbie doll" [translation mine] (Korwin-Mikke 2006a). In the Dictionary of Polish one can find a definition of the word "slut", with a colloquial classifier: "about a slovenly woman and - with contempt - about a promiscuous woman" (Sobol 1991, p. 273). "Old bag" is "an offensive term describing an unpleasant woman, especially an old and ugly one” (Bańko 1993, p. 93). In the Dictionary of Colloquial Polish [translation mine], a "doll” is a term describing "a pretty, attractive girl, a young woman" (Czeszewski 2008, p. 7). The axiology of the word "doll" changes in combination with the epithet "Barbie - Barbie doll" expresses the irony of a speaker, causing an adequate reaction of a receiver.

\section{Antifeminist aphorisms - a description of the male point of view}

J. Korwin-Mikke frequently takes up topics concerning women thanks to which he makes more enemies than friends. In order to understand why it happens, it should be enough to analyse some of his statements, for example: "Women are another category of handicap" (http://frizona.pl/threads/275-Cytaty-Janusza-Korwin Mikkego?p=39919\&viewfull=1).

His statements including women in the group of handicapped people must appal both female representatives and disabled people. Including all women in the category of the handicapped proves not only the author's prejudice against the opposite gender, but also his conscious, though irrelevant use of the term.

Z. Sękowska - a distinguished typhlopedagogist - has presented the following classification of the disabled people, who are described as:

- "having difficulties in cognizing the world and communicating with it, which results from the lack of sensory analysis;

- those whose cognitive processes are abnormal, which disturbs the image of the world, and whose cognitive, social and work abilities are seriously limited;

- those who - because of motor organ damage - have limited ability of self-expression and active participation in social life; 
- requiring rehabilitative education, as a result of neglect and upbringing errors, nervous system abnormality, psychopathy or personality disorder” (Sękowska 1985, p. 6).

In the Dictionary of Polish a disabled person is described as "a person who does not reach their physical or mental maturity" (Bańko 1992, p. 346). The previously cited thought of J. Korwin-Mikke seems bizarre in the context of these definitions. However, knowing his fondness for controversial statements, it seems that he wanted to underline the imperfection and weakness of the sex not able to manage certain issues when it is missing something.

A. Awdiejew has worded the rule of an accurate aphorism: "One of the conditions of a good aphorism is provoking reflection. As a result, it activates copying of paradoxical meaning" [translation mine] (Awdiejew 1992, p. 282). Then it is possible to produce a comic effect, which (in case of J. Korwin-Mikke's aphorisms) can amuse only other chauvinists.

The politician, characterizing women, goes even further and writes: "Women are wonderful creatures - they are a mediating link between men and children and we love children, don't we?" [translation mine] (Korwin-Mikke 2008a).

Understanding the thesis - "women are wonderful creatures" - is the starting point for the preceding aphorism. It seems that the author of those words speaks highly of women. One can even have the impression that he admires them. We could not be further from the truth the following part of the aphorism is in contrast with the initial thesis in the area of semantics.

It is enough to explain the crucial juxtaposition: "a mediating link" to understand the spite and irony of his statement. In the Dictionary of Polish one can find the explanation that a link "connects people or things" and it is also "a component of an organizational structure" [translation mine] (Bańko 1992, p. 492). The term "mediating" can be described as:

1. "Exhibiting indirect causation, connection or relation

2. Acting in comparison with two issues, phenomena, etc.: sharing some features of both;

3. Occupying a middle position; between two elements, stages of a process, phenomenon, structure, etc." [translation mine] (Merriam Webster Dictionary, http://sjp.pwn.pl/szukaj/pośredni).

Those definitions give clearly the understanding that a women is not perfect. She is somebody intermediate between a rational man and a reckless child. The rhetorical question “and we love children, don't we?" intensifies the impression of his antipathy towards women. According to J. Korwin-Mikke, they are like children, which may carry positive connotations of wonderful, charming but mindless creatures, but also belittles the female sex explicitly. 
The politician reveals his peculiar perception of women, writing: "A woman soaks up the outlook of a man she sleeps with. Eventually, Nature or God (we are not going to argue) has not designed a man to let hundreds of thousands of sperm cells go to waste; they permeate into a woman's body and convert her into the image of a man she belongs to" [translation mine] (Korwin- Mikke 2007a).

J. Korwin-Mikke proposes a thesis that a woman "absorbs the outlook of a man", and "adopts his views thoroughly" [translation mine] (Bańko 1992, p. 1004). This sentence is very ambiguous, because such a phrase intensifies the verb "sleep with", which means "have sexual intercourse" [translation mine] (Bańko 1992, p. 386). In this context "soak up" - "to permeate, to fill something thoroughly" [translation mine] (Bańko 1992, p. 1004) - refers to intimate contacts. The following sentence proves the correctness of such interpretation. "Hundreds of thousands of sperm cells" get into a woman's body and "convert" her, so they "bring some changes in order to improve" her [translation mine] (Bańko 1992, p. 999). J. Korwin-Mikke assumes that a woman needs transformation. According to the author of this aphorism, a man generously shapes the opposite gender "in his own image" because he has got every right to do so: "a woman belongs to him" so he owns her. In this way J. KorwinMikke consciously refers to the fragment known from the Bible, which describes the human creation. However, there is a fundamental difference - according to The Book of Genesis, God created a human being in His own image. It is worth analyzing the word "ādām - a human". "Linguistic research has proved that the noun a $\bar{d} \bar{a} m$ does not appear in a plural form and has an individual meaning »a human«, as well as a collective one »humans «" (Świerczek 2009, p. 42). The Book of Genesis says: "So God created man in his own image, in the image of God created he him; male and female created he them" (The Book of Genesis, 1:27). The words give grounds for a claim that a woman is to the same extent a human being as a man (Świerczek 2009, p. 42). Thus J. Korwin-Mikke's position is substantially wrong. Firstly, a man and in fact - his reproductive cells - play a part of God. Other humans belong to this God because he has created them. Secondly, J. Korwin-Mikke downgrades the value of women who are equal to men. Knowing the disposition of the conservative politician, calling up such associations has been a deliberate action. He has used such aphorisms to express his conviction of the inferiority of women, who only under the influence of men are able to strive for perfection. "Former theology associated the notion »image« with supernatural features of human beings - their spirituality and mind" (Świerczek 2009, p. 43). Such context would fit the concept of J. Korwin-Mikke - "converting" the gentle sex in the image of men would finally make women think like men, that is sensibly. 
The picture emerging from the politician's aphorism reveals his stereotypical perception of gender. According to J. Korwin-Mikke, women would not be capable of rational thinking without men, because they are imperfect. Such a radical and direct manner of criticising women particularly appals feminists who fight against gender discrimination and what is frequently derided by this chauvinistic politician.

\section{Wordfight with "feminazis" - neologisms}

J. Korwin-Mikke can be classified as a sexist columnist. It is hard to disagree that he has captured the existing social stereotypes of feminists. According to J. Korwin-Mikke, "feminists themselves are co-authors of those stereotypes" [translation mine] (Jaxa-Rożen 2005 , p. 116). The politician says that: “(..) in a normal society a woman does not fight against her man but she loves him. He earns a living (...) and he is proud of it (and himself!). He gets this satisfaction for his own money" [translation mine] (Korwin-Mikke 1997b, p. 42).

In this fragment it is worth paying attention to the possessive pronoun 'his'. J. KorwinMikke perceives everything in the categories of owning and belonging. Since a woman depends financially on a man who 'makes a living', she should not fight against him. Against is a 'preposition binding a name of a person who is going to be hurt by someone' [translation mine] (Bańko 1992, p. 960). In the context of the preceding definition, a woman may hurt a man. Using a contrast, the politician claims that such a situation does not occur 'in a normal society' but the modern society is different - women start to rebel and want to earn their own money. His thesis is then easy to interpret: We live in an abnormal community. Women who decide to be self-reliant stand against the "right" order of the world because they try to free themselves from the power of men. J. Korwin-Mikke calls them "feminazis". "Please notice: feminazis (actually, their hidden leaders of male gender, of course!) protect women from men very carefully" [translation mine] (Korwin-Mikke 1997b, p. 42).

Combining prefixation and the element: femi- makes the neologism a subset. The significant part of the subset complete the information contained in the basic word - "nazis" which exists in the lexicon.

J. Korwin-Mikke has created a new word, combining the element "femi" with the word deriving from 'nazism' which describes one of the most cruel political systems in the history of mankind.

He has manifested his aversion to feminists very clearly. This neologism is a relatively new structure, because "a word may be classified as a neologism only in a clearly defined range of time" [translation mine] (Smółkowa 2001, p. 13). 
As we know, neologisms are innovative and exceedingly original but they quickly come into common use and after some time they are no longer new words.

J. Korwin-Mikke's neologisms are instantly recognizable by the receivers. They are created "depending on the limits of a language" [translation mine] (Smółkowa 2001, p. 17). The politician expresses his conviction - "of course!" - that feminists are certainly controlled by men. It seems that J. Korwin-Mikke does not believe that "a woman could be the head of any community" [translation mine] (Jaxa-Rożen 2005, p. 117).

"Neologisms can be divided into two macroareas: HUMAN BEING and HUMAN ACTIVITY. The macroarea HUMAN BEING consists of two thematic groups: 1) HUMAN BEING AS AN INDIVIDUAL and 2) HUMAN BEING AS A SOCIAL ENTITY. The second group of the macroarea - HUMAN BEING - consists of the names of people doing a particular job, the names of people belonging to particular community groups and having different views, interests" [translation mine] (Smółkowa 2001, p. 102). The example of "feminazis" can be assigned to this group.

T. Smółkowa claims that "neologisms are the result of the nomination process in its full complexity, also the psychological and cultural one" (Smółkowa 2001, p. 38). Constant social and economic development is connected with the appearance of neologisms. J. KorwinMikke gives the personal names which are connected with the world of politics, e.g. "eurofeminists" (Korwin-Mikke 2003), "euro-fascists" (Korwin-Mikke 2008b). The European Union is called "€roland" (Korwin-Mikke 2009a), the money - "€uroris" (Korwin-Mikke 2008d). The words start with a graphic innovation, the symbol of the currency. One can find other neologisms in his numerous columns and on his Internet blog. Some of them are prosaic, e.g.: "telestages" (Korwin-Mikke 2009h). The common characteristics of the new words are expressiveness and spite which is typical of such a "colourful" politician.

As T. Smółkowa has noticed: "common lexicon is the most stable one. It changes slowly, does not gain many new words and they belong to specific thematic areas. However, erudite and abstract lexicon changes and increases at a fast pace" (Smółkowa 2001, p. 87). J. Korwin-Mikke's neologisms prove the preceding thesis. Moreover, they are not limited only to the spoken language but they also function within langue (Smółkowa 2001, p. 17). We should not forget that the politician in the first place polemises with women's attitude to social problems and comments on political issues. That is why the majority of his neologisms are connected with those specific topics. 


\section{Language provocation}

J. Korwin-Mikke frequently irritates feminists pretending that he identifies with their ideas. This way he stirs up women and men, persuading them to criticize feminists' initiatives and demands. Using different means of expression, the politician is thought provoking. He consistently uses - according to the postulates of feminists - the feminine endings in the names of professions, e.g. "pisarka" (=writress) (Korwin-Mikke 2008b), "astronomka" (Korwin-Mikke 2009g), "psycholożka" (Korwin-Mikke 2008b), "publicystka" (KorwinMikke 2007b), “adwokatka”, "biznesmenka” (Korwin-Mikke 2009c). "Ka” is a Polish suffix indicating that the profession is practiced by a woman [translation and commentary mine] (Korwin-Mikke 2009c). It is a well-known fact that the names of professions are normally dominated by masculine forms. Using feminine forms carries ironic connotations and is perceived as less serious, although the situation is beginning to change. Such personal names have a much narrower semantic range, so they are not used as frequently as the masculine forms. Feminists try to fight with it and use the suffix-ka with all proper nouns determining their gender. In The Great Dictionary of Polish Usage (Markowski 2007, p. 934) there is a definition of "psycholozka" - with the community qualifier - "a female psychologist". The colloquial and ironic qualifier is the word "adwokatka" which means "a female lawyer" and "a woman who speaks in defence of someone or something". Next, "biznesmenka" is a colloquial word meaning "Ms. businesswoman". Only the words "autorka" (=author) and "publicystka" (=publicist) are the universally acknowledged feminine forms. The dictionary contains only the masculine form of a word "astronom" (=astronomer) and it advises using gender indicators, e.g. Ms., in order to communicate unambiguously.

A qualifier "informs that a particular lexical unit belongs to the group of marked vocabulary, characteristic of certain varieties of a language, used in specific communicative situations. It can also fulfil a valorizing function - it defines which lexical units may be used in a particular type of language contact" [translation mine] (Żmigrodzki 2005, p. 68-69). Colloquial or ironic community qualifiers - in case of the preceding feminine forms of professions - confirm that in the Polish language those forms were accepted only by a specific group. It is hard to find prestigious, feminine professions which would have feminine morphological endings accepted by the whole society.

Knowing J. Korwin-Mikke's views on women it can be assumed that the politician uses feminine forms of professions mostly because he treats women as "intermediate creatures". According to him the gentle sex should not be described with the same names because they are reserved only for men. Therefore, all the feminine formations used in his 
texts underline flippant, childish - that is - women's attempts to take up professions which are not assigned to their gender. In this manner, J. Korwin-Mikke highlights the superiority of male gender, which is conveyed in the following fragment: "A Polish female has discovered (by the way - with the use of a telescope built by men, a computer built by men and a computer program written by men) a new star, that will not have any influence on the future of Mankind" [translation mine] (Korwin-Mikke 2009g).

In the foregoing statement one should mark out two associated scripts: S1 - the discovery of a new star by a Polish female astronomer and S2 - lack of influence of the new discovery on the future of Mankind.

Opening a sentence with a statement: "A Polish female astronomer has discovered (...)" arises the curiosity of a receiver. The lexeme "discover" carries a few meanings:

1. "To unveil something what was covered; to reveal what was hidden;

2. To make known what was obscure, to come across something what has not been known before;

3. To pay attention to something what has not been noticed before" [translation mine] (Bańko 1992, p. 457).

The foregoing meanings arouse people's desire to gain knowledge of a great breakthrough discovery. Yet the "female astronomer" discovers "a new star" - therefore something ordinary - that everyone can notice with the help of a telescope, not being an astronomer. Adding the information that it will not have any influence on the "future of Mankind" intensifies the ridiculous nature of the astronomer's actions who was probably proud of herself and believed that she would influence the history of all people. However, the author of those words "incidentally" adds a quite important information that it was men who have achieved something truly important, because they have demonstrated their mental powers - built the telescope, wrote a computer program.

J. Korwin-Mikke mocks women who think that they have achieved a lot but forget that they would not do much without the foundations laid by men. Another example proves the foregoing conclusions true: "A man invents a dishwasher and then a woman puts dishes into it and presses the buttons. And they are both happy [translation mine] (Korwin-Mikke 2009g).

In this fragment women are presented in a grotesque manner. The author assumes that the apex of women's possibilities is to learn how to use a dishwasher and this knowledge satisfies them. J. Korwin-Mikke evaluates each gender by the verbs he uses. He shows 
a positive image of a man who does extraordinary things - he "invents" so he "discovers or works out on something new" [translation mine] (Bańko 1992, p. 824). The verbs assigned to a woman - "put, press" - do not denote anything complicated and do not even require thinking. According to J. Korwin-Mikke, "they are both happy" because men are born to analyse and discover, whereas women are happy when they perform the most basic activities. Only feminists are able to destroy the order and harmony of feminine-masculine relations. "Of course, until feminists arrive and convince women that since they have not invented a dishwasher or at least discovered a star - they are worse than men" [translation mine] (Korwin-Mikke 2009d).

J. Korwin-Mikke alludes to the rebellious nature of feminists' actions who destroy the order and former satisfaction of both genders. The politician emphasizes feminists' actions who arrive - "visit someone with a specific aim" [translation mine] (Bańko 1992, p. 1041) and "convince", meaning - "to prove that something is true with the use of arguments, change someone's attitude" [translation mine] (Bańko 1992, p. 979). Comparing achievements dispirits women who realize that they are inferior to men. According to J. Korwin-Mikke, men and women live happily ever after until feminists arrive. This way certain associations are created and they automatically present the clash of good and evil. Feminists are, of course, the villains the politician, writing openly what he thinks about them, is aware of the hatred he arouses.

"Feminists don't like me, but feminists hate women. Feminists believe that only what is masculine is important and what women do is insignificant" ( http://warszawa.gazeta.pl/warszawa/1,76015,3116930.html).

In the complex coordinated clause with an adversative conjunction $(\rightarrow \ldots<-)$ the two verbs expressing feelings are contrasted by means of the conjunction ,ale” [but]. The use of the two verbs ,nie lubic" [not like] in respect to an antifeminist, and a definitely stronger one, "nienawidzic" [hate] in respect to all women is surprising, but deliberate. The next complex coordinated clause is contrasted with the conjunction "a [and]" makes an opposition masculine - feminine by means of the antonyms: "important - insignificant". The politician exaggerates in this way the behaviour of feminists who, in his opinion, are focused on levelling men to such an extent that everything women have done so far seems to be of little value.

„There are maybe 300 warring feminists in Poland; these are men who want equality of rights so that they don't have to work for women's living and the feminists serve them, as if they were stupid, as a screen [for their activities]" (Korwin-Mikke 2009e). 
The present participle points to the main feature of the agent, which is doing war. Warring, or "fighting fiercely for their ideals" (Bańko 1992, p. 745) feminists want something which turns out to be a male intention. The politician derides feminists by calling them stupid and comparing them to a tool used by men for their real purposes.

Korwin-Mikke in one interview claims: „Feminists are agents of men, really. They are complete idiots, that's all” (http://warszawa.gazeta.pl/warszawa/1,76015,3116930.html).

The politician notices that feminists are "agents", or "secret workers" (Sobol 1991, p. 25) of men. By means of the particle naprawde [really] he wants to "encourage his audience in the correcctness of his judgement and in this way confirms its genuineness" (Bańko 1992, p. 279). Calling them idiots, or mentally disabled people or offensively stupid (about a person), expresses his negative emotions which the politician has for fighting "not in favour of but against women", feminists (http://warszawa.gazeta.pl/warszawa/1,76015,3116930.html). J. Korwin-Mikke does not only address feminists with insulting phrases, but also fails to follow their proposition as he refers to women in a way that is found shocking for feminists, e.g. "I, dear Mrs. Kolendo-Zalewsko (peculiar use of endings, traditionally attached to female surnames; not commonly used nowadays), publicist (with an ending characteristic of the feminine; not commonly used) find Mrs. Aneta Krawczykowa (peculiar use of endings, traditionally attached to female surnames; not commonly used nowadays) not a «a perverted woman», which sounds exciting, but a common whore" (Korwin-Mikke 2007b).

The way of addressing Mrs Kolenda-Zaleska, in addition to a mistake in the second part of her surname, ("Zalewsko" instead "Zalesko") is declined according to the rule of the double-barrelled surname declination. In short, "each part of the double-barrelled female surnames which end with »a« in the nominative is declined" (Grzenia 2003, p. 64-65). The suffix -owa is added to the next surname, which clearly marks the dependence on the masculine form. A female surname derived from the husband's name, in this case it is "Krawczykowa", contains in its genesis a factor of belonging to or possession - Krawczyk's wife.

Feminists fight against the loss of their identity and more often than ever, as in the case of Mrs Kolenda-Zaleska, decide to take a double-barrelled surname which contains both their surname and their husbands' surname.

J. Korwin-Mikke keeps reminding women who have taken their husbands' surnames in marriage of their dependence on them, e.g. "Sometimes, I have a look at the blog of Mrs Prof. Senyszynowa for entertainment" (Korwin-Mikke 2009b). "[Ms] countess Beata 
Tyszkiewiczowa has recently said that men "srow strange with age and adopt female features«" (Korwin-Mikke 2009f).

The politician deliberately uses the feminine form ending with - owa, as well as, all titles for women. It is worth noticing that preserving only the family name, as in the case of Mrs B. Tyszkiewiczowa, has never been a common practice. Such a decision is only made by women who have already become publicly recognized before their marriage, e.g. by actresses, journalists, painters or scientists. It must be pointed out that in this case J. Korwin-Mikke violates a linguistic norm by adding the suffix - owa instead of - ówna to the maiden name: Tyszkiewicz.

The politician does not only tend to add all important titles, but also polonises the names of well-known foreign people, especially women, which often has a comical effect, e.g. "lady Małgorzata Thatcherowa", "Mrs. Aniela Merkel (Prime Minister with a feminine suffix in Polish) of RFN", "Mrs Hilaria Clintonowa" (Korwn-Mikke 2008c).

Polonisation of names is a procedure stylistically marked. Bearing in mind J. KorwinMikke's traditionalism and patriotism, one can attempt to understand his behaviour. Yet, Polish equivalents of foreign names of well-known and respected people sound funny and they cannot escape grotesqueness which is the desired effect. J. Korwin-Mikke fails to observe the rule that "the names of living people of other than Polish nationality should be written in the original visual form, even if they have Polish equivalents" (Polański 2006, p. 96). It is difficult to say whether consistent polonisation of names and addition of suffixes denoting possession to men to names are just evidence for his conservatism or yet another attempt to dominate the opposite gender.

Rarely does J. Korwin-Mikke refrain from acerbic comments. Cynicism and acrimony define his attitude towards the world. Having read an article in "Polityka", J. Korwin Mikke took interest in S. Sierakowski and started reading the "guru of the left" (Korwin-Mikke 2008d). He was irritated to such an extent that he juxtaposed S. Sierakowski's conclusions with female ones: "It might as well be written by Mrs. E. Tomaszewska (CEP), Mrs. M. Gretkowska or any other deficient extreme leftist (with a feminine suffix) »understanding« with womb(...). Can a normal person, who knows that greater merit should be gratified with a greater reward, believe that »more equally « = »more justly«???” (Korwin-Mikke 2008d).

It has been a well-known fact in Polish culture that comparing a man to a woman is the greatest disregard which always has a negative meaning. In this statement J. KorwinMikke did not only offend his political rival, but in first place, he offended women whom he described in a vulgar way. 
The use of the linguistic phrase "deficient extreme leftist (with a feminine suffix) »understanding « with womb” discloses definitely negative emotions. M. Grochowski noticed that the expressions describing certain parts of the body are improper and will not receive the approval of linguistic behaviour depending on the use of them. It seems that the user of a language is aware of a certain "self-censorship; they know that by means of some sound sequences (strings of letters) language taboos can be transgressed" (Grochowski 2002, p. 15). What is interesting, J. Korwin-Mikke rarely uses offensive words in this way. Despite this, saying so, he wrongly offended not only Mrs E. Tomaszewska or M. Gretkowska, but also every female member of the left which is "a political party that opts for social justice, egalitarism and necessity of progress" (Bańko 1992, p. 27). In the subchapter on neologisms I noticed that J. Korwin-Mikke coins more new words connected with politics and women than anybody else.

The phrase an extreme leftist is a good example of a neologism which joins the gender with politics. The neologism - an extreme leftist - belongs to the macroarea - HUMAN - and is a part of the thematic group: HUMAN AS A SOCIAL BEING which consists of "names of definite people based on their views and the sense of belonging [to a group]" (Smółkowa 2001, p. 102). The present participle taken in inverted commas - "understanding" - was used to mark the distance from the activity carried out by the extreme leftists. It means that the politician doubts whether they would be able to understand, or "deal with issues by means of conclusion” (Bańko 1992, p. 126). By joining ,„understanding“ with the womb” - „the female reproductive organ" (Bańko 1992, p. 85), J. Korwin-Mikke belittled the female value and derided women's intellect. The comparison of the way of creating thoughts by $\mathrm{S}$. Sierakowski to the female thinking - "»understanding« with the womb" - deprecates him since it points to stupidity, the lack of thinking and logic in his statements, which comprises the characteristics a real man should not have. The rhetoric question aims at ridiculing women and S. Sierakowski since it suggests that if they believe in such utopian slogans which they propagate, they cannot be normal. As a result, the whole statement deprecates mainly the feminine gender as the very comparison is the most pejorative for them.

No doubt, J. Korwin-Mikke finds a whole range of supporters who appreciate him both as a politician and a renowned publicist. These are people who sometimes support his worldview and, like him, are certain that only a man can write about reality in a normal or real way. However, there are many people who follow his utterances due to the interest in his new linguistic inventions used to fight with feminists. 
H. Jaxa-Rożen claims that there is ample evidence that J. Korwin-Mikke is a "convenient exponent of »the silent majority« of politicians who due to their position cannot formulate their opinions about women in such a straightforward way" (Jaxa-Rożen 2005, p. 117). One cannot show indifference towards J. Korwin-Mikke's utterances. Probably, that is why he has so many ardent supporters as he has opponents. It seems he gains enormous satisfaction from situations in which he can move or offend, especially feminists, with his sharp remarks. He willingly takes up topics started by women and deals with them, in his opinion, "normally", like a man, and as it should be done.

\section{Bibliography}

Awdiejew A. (1992), Nieśmieszne aforyzmy (Refleksja nad semantykq humoru Viktora Raskina), [in:] Nowakowska-Kempna I., (eds.), Język a kultura. V.8: Podstawy metodologiczne semantyki współczesnej, Wiedza o Kulturze, Wrocław.

Bańko M., Krajewska M., Sobol E (eds.) (1993), Słownik języka polskiego: suplement, PWN, Warszawa.

Bańko M., Krajewska M., Sobol E. (eds.) (1992), Słownik języka polskiego, PWN, Warszawa. Czeszewski M. (ed.) (2008), Słownik polszczyzny potocznej, Second Edition, PWN, Warszawa.

Grochowski M. (ed.) (2002) (red.), Stownik polskich przekleństw i wulgaryzmów, PWN, Warszawa.

Grzenia J. (ed.) (2003), Stownik nazw własnych, PWN, Warszawa.

Jaxa-Rożen H. (2005), Kontestacja i banat: feminizm $w$ kulturze współczesnej, Atla 2, Wrocław.

Korwin-Mikke J. (1997b), Feminazistki, „Playboy” 1.

Markowski A. (ed.) (2007), Wielki słownik poprawnej polszczyzny PWN, PWN, Warszawa.

Nowakowska-Kempna I., (1992) (eds.), Język a kultura. V.8: Podstawy metodologiczne semantyki współczesnej, Wiedza o Kulturze, Wrocław.

Polański E. (ed.) (2006), Wielki słownik ortograficzny PWN z zasadami pisowni i interpunkcji, PWN, Warszawa.

Sękowska Z. (1985), Pedagogika specjalna: zarys, PWN, Warszawa.

Smółkowa T. (2001), Neologizmy we wspótczesnej leksyce polskiej, IJP PAN, Kraków.

Sobol E. (ed.) (1991), Stownik wyrazów obcych, PWN, Warszawa.

Świerczek E. (2009), Bóg Starego testamentu, Wydawnictwo Calvarianum, Kraków. 
Żmigrodzki P. (2005), Wprowadzenie do leksykografii polskiej, Wydawnictwo Uniwersytetu Śląskiego, Katowice.

\section{Netography}

Merriam Webster Dictionary, http://sjp.pwn.pl/szukaj/pośredni, retrieved: 29.03.2010.

http://frizona.pl/threads/275-Cytaty-Janusza-Korwin $\quad$ Mikkego?p=39919\&viewfull=1, retrieved: 29.03 .2010 .

Korwin-Mikke J. J (2003), http:/korwinmikke.pl/dziennik_polski/zobacz/dyskryminacja/1133, retrieved: 06.04.2010.

Korwin-Mikke J. (2006a), http://korwin-mikke.pl/angora/zobacz/z kim przestajesz/76, retrieved: 09.04.2010.

Korwin-Mikke J. (2006b), http://warszawa.gazeta.pl/warszawa/1,76015,3116930.html, retrieved: 30.03 .2010 .

Korwin-Mikke (2007a), http://korwin-mikke.blog.onet.pl/1,DA2007-08-23,index.html, retrieved: 28.03.2010.

Korwin-Mikke J. (2007b), http://korwin-mikke.blog.onet.pl/1,DA2007-02-14,index.html, retrieved: 30.03.2010, 05.04. 2010.

Korwin-Mikke J. (2008a), http://korwin-mikke.blog.onet.p1/1,DA2008-03-08,index.html, retrieved: 29.03 .2010 .

Korwin-Mikke J. (2008b), http://korwin-mikke.blog.onet.pl/1,AR3_2008-04_2008-0401_2008-04-30,index.html, retrieved: 30.03.2010, 06.04.2010.

Korwin-Mikke J. (2008c), http://korwin-mikke.blog.onet.pl/1,AR3 2008-11 2008-1101 2008-11-30,index.html, retrieved: 05.04.2010.

Korwin-Mikke J.(2008d), http://korwin-mikke.blog.onet.pl/Szemrany-guru,2,ID309385349,n, retrieved: 05.04.2010.

Korwin-Mikke J. (2008e), http://korwin-mikke.blog.onet.pl/1,DA2008-1122,index.html,06.04.2010.

Korwin-Mikke J. (2009a), http://korwin-mikke.blog.onet.pl/1,AR3_2009-03_2009-0301_2009-03-31,index.html, retrieved: 06.04.2010.

Korwin-Mikke J. (2009b), http://korwin-mikke.blog.onet.pl/1,AR3_2009-01_2009-0101_2009-01-31,index.html, retrieved: 05.04.2010.

Korwin-Mikke J. (2009c), http://korwin-mikke.blog.onet.pl/1,DA2009-08-19,index.html, retrieved: 30.03 .2010 . 
Korwin-Mikke J. (2009d), http://korwin-mikke.blog.onet.p1/1,DA2009-03-08,index.html, retrieved: 30.03 .2010 .

Korwin-Mikke J. (2009e), http://korwin-mikke.blog.onet.pl/1,DA2009-11-17,index.html, retrieved: 30.03 .2010 .

Korwin-Mikke J. (2009f), http://korwin-mikke.blog.onet.pl/1,DA2009-11-24,index.html, retrieved: 06.04.2010.

Korwin-Mikke J. (2009g), http://korwin-mikke.blog.onet.pl/Czym-jestkobieta,2,ID368068361,n, retrieved: 29-30.03.2010.

Korwin-Mikke J. (2009h), http://korwin-mikke.blog.onet.pl/1,AR3_2009-07_2009-0701_2009-07-31,index.html, retrieved: 06.04.2010. 